\title{
THE EFFORT OF THE QUALITY OF SEAPORTS ON FREIGHT ROUTING
}

\author{
A.Kaukin, E.Filicheva
}

An analysis of the freight costs of Russian foreign trade cargos shows that the quality characteristics of Russia's seaports have a strong bearing on the sea freight routing - seaports with low-quality infrastructure are apt to lose the competition. Not only Russia's economic policy in the context of foreign trade should be constructed towards focusing on enhancing the terminals throughput of Russia's seaports, but it also should address the quality of their infrastructure.

The chiefly favorable macroeconomic situation in the 2000s gave momentum to the development of freight infrastructure in Russia. The sea transport infrastructure saw stable investment inflows and substantial growth in fixed assets whose value doubled in the period between 2000 and 2013 (Fig. 1). That period was marked by grand projects, of which the most prominent were the construction of a virtually new seaport in Ust-Luga, the completion of the construction of special-purpose oil loading ports in Primorsk and Kozmino, the capacity enhancement and the creation and the throughput enhancement of the specialpurpose terminals in the seaports of St. Peterburg, Novorossiysk and Vladivostok.

However, investment have been focused chiefly on projects aimed at enhancing the existing capacities, increasing the physical throughput, rather than those intended to enhance the qualitative development of the seaport infrastructure. Furthermore, such projects may not always be in line with forecasts on volumes and routing of Russia's foreign trade. For example, plans of the enhancement of the seaport throughput to 94 million tons in $\operatorname{Taman}^{1}$ by 2020 were approved in 2013. Once all of the projects in the Black and Caspian Sea basins are fulfilled, the total throughput of Russia's seaports in this region may reach about 360 million tons in 2020 . However, according to a project called the Development Strategy of the Seaport Infrastructure in Russia until $2030^{2}$, the total freight traffic via Russia's seaports in the Black and Caspian Sea basins in 2020 may be from 257,8 million tons under an energy-resource scenario till 274,8 million tons under an innovative scenario. Furthermore, the potential of rerouting

\footnotetext{
1 "Prime Minister Medvedev approves an action plan for the development of the Taman seaport" // RIA Novosti's news portal, available at, http://ria.ru/economy/20131229/987092097.html

2 A draft development strategy project was approved at a meeting of the Marine Board under the Government of the Russian Federation (the Minutes of 28.09.2012 No. 2(18)). A refined draft development strategy project is scheduled for consideration in June 2015 at the level of Russia's government.
}

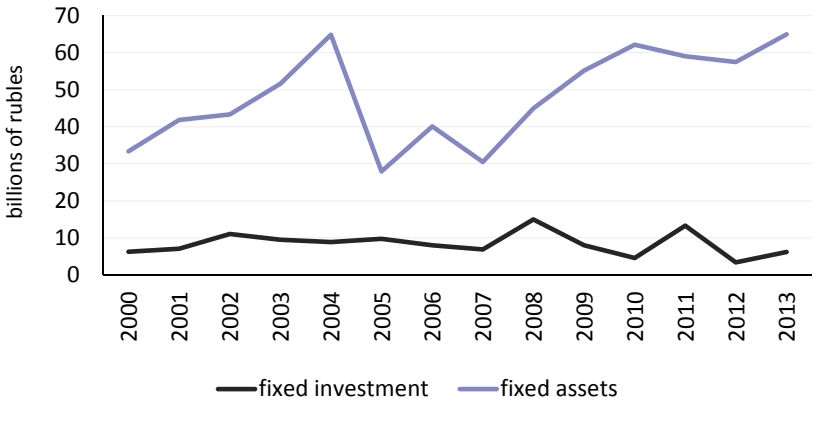

Source: The Federal State Statistics Service (Rosstat). Fig. 1. Investment behavior in Russia's sea transport sector in 2000-2013 (current price)

Russian cargos from Ukrainian to Russian seaports is equal or less than 19 million tons a year ${ }^{3}$. Since the forecast was made even before the introduction of basic trade sanctions and the ruble's depreciation, the forecast on foreign trade volumes can be expected to see a downgrade given the current circumstances. This implies that Russia's seaports in the Black and Caspian Sea basins will run excess capacities by 2020, even though Russian it would be impossible for geopolitical reasons to transship Russian cargos at Ukrainian seaports.

While selecting the itinerary of freight items, cargo owners are guided by both price-related and other than price-related factors ${ }^{4}$. The price-related factors is the value of logistic chain elements along the entire itinerary of freight items, for example, freight rate, port dues, pilotage costs, cargo transshipment costs, train and road haulage costs. The other than price-related factors are qualitative characteristics of

3 The freight volume of Russia's cargos via Ukrainian ports in 2013, according to the data provided by JCSC Morcentr-TEK.

4 In this case, it is the factors of the competitive power of certain seaports, not the country at large, that are referred to. The recent ones are provided in, for example, the paper of Knobel A. Y., Poiker M. B.. The key indicators of the competitive power of Armenia, Moldova and Tajikistan in the context of trade and economic cooperation with the Customs Union // Rossyisky Vnesheekonomichesky Vestnik, No. 6, 2013. pp. 15-27. 
seaports which have an impact on the transshipment duration and make given seaport services available. The key factors of "quality" competitive power of a seaport include the navigation availability (depth, channels, navigation season), the quality of seaport services (pilotage, hauling, mooring), the quality and availability of infrastructure (availability of specialpurpose terminals, warehouses, floor space), the quality of administration, storage services and overland cargo movement services, etc. For example, a deeper near-shore zone allows seaports to serve heavy-tonnage vessels with deeper draft, which is quite an important feature given the recent uptrend in vessel tonnage which has been prevailing for the past decade. By contrast, narrow, several-tenskilometer long and winding access channels hinder vessels entering a seaport and consume more costs and time. The qualitative development, rather than the quantitative enhancement of the throughput of a seaport suggests, above all, lower costs for cargo owners, which are not directly related to freight costs.

To measure the effect of other than price-related factors on the transport and freight routing, the IAER RANEPA ${ }^{1}$ made a comparative analysis of the optimal (in terms of price costs) with the actual freight routing across the Russian border. Price of costs of transportation were calculated separately for cargos of various types as total of freight costs and port duties along the sea shipment chain, cargo handling costs, car-carrier truck transportation costs (the average rate per 1 ton/ kilometer charged by large and medium-sized motor transport carriers) and the costs of shipment by rail (based on the Price List 10-01 "The tariffs on the freight and infrastructure services rendered by the Russian Railways") along the overland shipment chain.

The results of the comparative analysis of transportation costs on the existing and alternative foreign trade routes show that cargo owners not always pick the lowest-cost chain of shipment of imported goods to Russia. In other words, the results obtained show that other than price-related factors of the transport infrastructure are very important for cargo owners.

For example, in 2013, motor vehicles were supplied from Japan to Moscow through the seaports in the Baltic Sea: both through the Big Seaport of St. Petersburg and the seaport in Ust-Luga. The total estimated transportation costs at the Big Seaport of

1 The bottlenecks of Russia's seaport infrastructure were detected and analyzed by measuring the competitive power of the key foreign trade chains of supply // The research work performed as part of the state assignment by the RANEPA under the President of the Russian Federation, 2014.
St. Petersburg is lower than that at the seaport in UstLuga: by about $\mathrm{Rb} 2,000$ per each 20 tons of cargo $^{2}$ according to the "sea freight + railway freight" scheme or by $\mathrm{Rb} 80,000$ according to the "sea freight + road freight" scheme ${ }^{3}$. For supplies of this type, the freight costs have no higher priority to the consignor over other terms of transshipment in the given seaport, whereas the seaport in Ust-Luga appears to be more competitive versus the Big Seaport of St. Petersburg in terms of other than price-related parameters. The stronger competitive power of the Ust-Luga seaport versus the Big Seaport of St. Petersburg is partly due to the fact that the latter has a longer access channel, sever navigation conditions and stricter draft requirements for vessels. Additionally, the Ust-Luga seaport has more advanced high-capacity special-purpose terminals and equipment. Overall, the deficit of capacities for handling the increasing volume of cargos at the Big Seaport of St. Peterburg has forced it to refocus a part of the cargo traffic to the neighboring seaports ${ }^{4}$. It is worthwhile noting that the motor and railway access routes to both seaports have limiting lines, which despite the formal reserve throughput of the terminals, has an adverse effect on their competitive power versus some of the foreign Baltic seaports. Vehicles from Japan to Moscow were also supplied through Brusnichnoye and Svetogorsk, the Russian-Finnish automobile border patrol checkpoints (to do so, the goods have to first be shipped to a foreign seaport, e.g., Helsinki ${ }^{5}$ or Kotka, and then to the consignee by land), thereby showing that foreign seaports are more appealing for cargos of this type.

Another example of the actual trade routes deviation from the optimal ones identified through the assessments, is supplies of machinery and equipment and light industry goods from China to Moscow. In 2013, these goods were supplied via both Russia's seaports in the Baltic Sea and the Russian-Finnish automobile border checkpoints: Svetogorsk, Torphyanovka and Brusnichnoye. The total freight costs through Russia's seaports are about 30\% less than those through foreign seaports given a longer shipment by land and almost similar sea freight rates. However, most of the foregoing goods were supplied through

2 Equal to the total load of a car-carrier truck or railway car carrier as most typical means of transport for cargos of this type.

3 The difference can be explained by the fact that Ust-Luga is situated (by land) 130 kilometers further from Moscow than St. Petersburg.

4 According to the data provided by CJSC Morcentr-TEK, in 2014 , the Big Seaport of St. Petersburg (61,1 million tons, $+5.4 \%$ by 2013 ) ceded its leadership among Russia's seaports in the Baltic Sea to the seaport in Ust-Luga (75,7 million tons, $+20.3 \%$ by 2013 ). 5 The seaport in Vuosaari (an integral part of the seaport in Helsinki) alone has a capacity of 800,000 units of rolling cargos a year. 
foreign seaports - the volume of China-made machinery and equipment supplies through the Big Seaport of St. Petersburg was almost three times less than that through the automobile border checkpoints in Svetogorsk, Torphyanovka and Brusnichnoye. This is determined by the specialization of foreign seaports and the development of the respective terminal infrastructure: for example, since the transportation inside containers is the most worthwhile way of shipment of a very wide range of goods, a seaport should be properly equipped to accept, load, unload and store them in order to be attractable. However, the Russian seaports are still lagging in this aspect behind many of their foreign competitors.

It is worthwhile noting that certain types of supplies are undertaken only through a single seaport which may not be leading in the transshipment in the area, or a seaport with the lowest price costs of shipment.
For example, in 2013, minerals and iron and steel-made goods from Finland to St. Peterburg or the Leningrad Region were supplied through the sea border checkpoints in Brusnichnoye, Vyborg and Vysotsk, rather than through the Big Seaport of St. Petersburg. The hypothetic route through the Big Seaport of St. Petersburg is more worthwhile due to a shorter shipment by land, although at a slightly higher sea freight rate.

Some of the other cases of deviation from the optimal shipment in terms of price costs are presented in Table 1 (the Baltic Sea basin is shown as an example).

$* * *$

Analysis of the results of the comparison between Russia's transportation chains of foreign trade supplies of goods with cargo transshipment at seaports shows that while choosing a shipment itinerary, consignors pay attention to not only the overall transportation

Table 1

THE EXAMPLES OF THE DEVIATION OF GOOD FLOWS FROM OPTIMAL ROUTES IN TERMS OF SHIPMENT COSTS ${ }^{A}$

\begin{tabular}{|c|c|c|c|c|c|}
\hline $\begin{array}{l}\text { Country } \\
\text { of origin }\end{array}$ & $\begin{array}{l}\text { Region of } \\
\text { destination }\end{array}$ & Cargo type & $\begin{array}{l}\text { The optimal ship- } \\
\text { ment route based } \\
\text { on the price } \\
\text { costs through }\end{array}$ & $\begin{array}{l}\text { Border checkpoints of } \\
\text { actual shipments }\end{array}$ & $\begin{array}{l}\text { The share of oth- } \\
\text { er than optimal } \\
\text { shipment routes } \\
\text { in total value }\end{array}$ \\
\hline Japan & $\begin{array}{l}\text { Moscow and } \\
\text { the Moscow } \\
\text { Region }\end{array}$ & $\begin{array}{l}\text { Cars and motor } \\
\text { vehicles }\end{array}$ & $\begin{array}{l}\text { The Big Seaport } \\
\text { of St. Petersburg }\end{array}$ & $\begin{array}{c}\text { The Big Seaport of St. Petersburg, } \\
\text { Ust-Luga, Svetogorsk (APP), } \\
\text { Brusnichnoye (APP) }\end{array}$ & $>80 \%$ \\
\hline $\begin{array}{l}\text { South } \\
\text { Korea }\end{array}$ & Moscow & $\begin{array}{c}\text { Cars and motor } \\
\text { vehicles }\end{array}$ & $\begin{array}{l}\text { The Big Seaport } \\
\text { of St. Petersburg }\end{array}$ & $\begin{array}{l}\text { The Big Seaport of St. } \\
\text { Petersburg, Ust-Luga }\end{array}$ & $>40 \%$ \\
\hline Italy & Moscow & $\begin{array}{l}\text { Machinery and } \\
\text { equipment }\end{array}$ & $\begin{array}{l}\text { The Big Seaport } \\
\text { of St. Petersburg }\end{array}$ & Brusnichnoye, Vyborg, Vysotsk & $100 \%$ \\
\hline Germany & Moscow & $\begin{array}{l}\text { Machinery and } \\
\text { equipment }\end{array}$ & $\begin{array}{l}\text { Kronstadt (avant- } \\
\text { port BSPSP) }\end{array}$ & Kronstadt, Brusnichnoye, Vysots & $14 \%$ \\
\hline Finland & Moscow & $\begin{array}{l}\text { Machinery and } \\
\text { equipment }\end{array}$ & $\begin{array}{l}\text { The Big Seaport } \\
\text { of St. Petersburg }\end{array}$ & Brusnichnoye, Vysots & $100 \%$ \\
\hline Finland & St. Peterburg & Minerals & $\begin{array}{l}\text { The Big Seaport } \\
\text { of St. Petersburg }\end{array}$ & Brusnichnoye, Vyborg, Vysotsk & $100 \%$ \\
\hline Japan & $\begin{array}{l}\text { Nizhny } \\
\text { Novgorod } \\
\text { Region }\end{array}$ & Ferrous metals & $\begin{array}{l}\text { The Big Seaport } \\
\text { of St. Petersburg }\end{array}$ & Vysots & $100 \% *$ \\
\hline Germany & $\begin{array}{l}\text { Nizhny } \\
\text { Novgorod } \\
\text { Region }\end{array}$ & Ferrous metals & $\begin{array}{l}\text { The Big Seaport } \\
\text { of St. Petersburg }\end{array}$ & Vysots & $100 \% *$ \\
\hline Ireland & Moscow & $\begin{array}{l}\text { Chemical } \\
\text { products }\end{array}$ & $\begin{array}{l}\text { The Big Seaport } \\
\text { of St. Petersburg }\end{array}$ & Brusnichnoye, Vyborg, Vysotsk & $100 \% *$ \\
\hline China & Moscow & $\begin{array}{l}\text { Light industry } \\
\text { products }\end{array}$ & $\begin{array}{l}\text { The Big Seaport } \\
\text { of St. Petersburg }\end{array}$ & $\begin{array}{c}\text { Torphyanovka (APP), } \\
\text { Brusnichnoye (APP), Primorsk }\end{array}$ & $100 \%$ \\
\hline China & Moscow & $\begin{array}{l}\text { Machinery and } \\
\text { equipment }\end{array}$ & $\begin{array}{l}\text { The Big Seaport } \\
\text { of St. Petersburg }\end{array}$ & $\begin{array}{c}\text { The Big Seaport of St. Petersburg, } \\
\text { Primorsk, Svetogorsk (APP), } \\
\text { Mozzchevelnikovo (APP), } \\
\text { Brusnichnoye (APP) }\end{array}$ & $>70 \%$ \\
\hline
\end{tabular}

A Shipments along other than optimal routes can be explained, of cause, not only by higher quality of the infrastructure in rival ports, as noted above, but also a heavy load. In this case, in order to curtail consignors' costs, it may be worthwhile to enhance the throughput of a seaport, however, it can be done only through the construction of new terminals by shortening the time of cargo handling using the available capacities, i.e. by enhancing the quality of the seaport infrastructure. 
costs, but also other factors, qualitative characteristics of the seaport infrastructure: it may happen that more goods are supplied along routes with higher price costs than along those with low price costs. This suggests that the construction of Russia's economic policy in the context of foreign trade and the prioritizing of investment projects of the development of seaport infrastructure should be focused not only on enhancing the throughput of terminals but also the quality of Russia's seaport infrastructure. The analysis made allows such bottlenecks in the seaport infrastructural development to be explicitly detected. 